\title{
Salinity-gradient energy driven microbial electrosynthesis of hydrogen peroxide
}

\author{
Li, Xiaohu; Angelidaki, Irini; Zhang, Yifeng
}

Published in:

Journal of Power Sources

Link to article, DOI:

10.1016/j.jpowsour.2016.12.030

Publication date:

2017

Document Version

Peer reviewed version

Link back to DTU Orbit

Citation (APA):

Li, X., Angelidaki, I., \& Zhang, Y. (2017). Salinity-gradient energy driven microbial electrosynthesis of hydrogen peroxide. Journal of Power Sources, 341, 357-365. https://doi.org/10.1016/j.jpowsour.2016.12.030

\section{General rights}

Copyright and moral rights for the publications made accessible in the public portal are retained by the authors and/or other copyright owners and it is a condition of accessing publications that users recognise and abide by the legal requirements associated with these rights.

- Users may download and print one copy of any publication from the public portal for the purpose of private study or research.

- You may not further distribute the material or use it for any profit-making activity or commercial gain

- You may freely distribute the URL identifying the publication in the public portal

If you believe that this document breaches copyright please contact us providing details, and we will remove access to the work immediately and investigate your claim. 


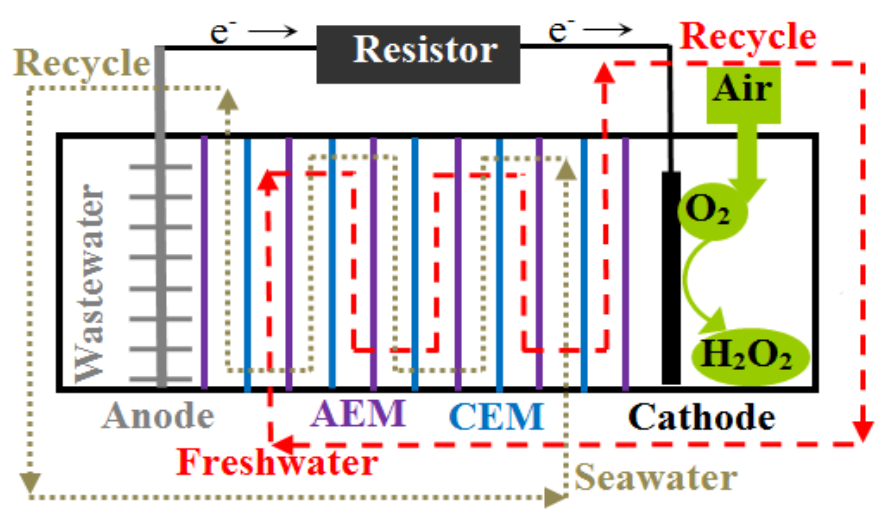




\section{Highlights}

- Microbial reverse-electrodialysis electrolysis cell for $\mathrm{H}_{2} \mathrm{O}_{2}$ production.

- High yield synthesis of $\mathrm{H}_{2} \mathrm{O}_{2}$ from oxygen reduction without external power supply.

- Salinity-gradient between salt and fresh water drove the high-rate $\mathrm{H}_{2} \mathrm{O}_{2}$ production

- Recycling the salt and fresh water for the production with less water consumption.

- Cathode potential as key for $\mathrm{H}_{2} \mathrm{O}_{2}$ production can be adjusted by air flow rate. 
Submission to Journal of Power Sources

Salinity-Gradient Energy Driven Microbial Electrosynthesis of Hydrogen Peroxide

Xiaohu Li, Irini Angelidaki, Yifeng Zhang*

Department of Environmental Engineering, Technical University of Denmark, DK-2800

Lyngby, Denmark

*Corresponding author:

Dr. Yifeng Zhang

Department of Environmental Engineering, Technical University of Denmark, Denmark Tel: (+45) 45251410.

Fax: (+45) 45933850.

E-mail address: yifz@env.dtu.dk; yifzmfc@gmail.com 


\section{Abstract}

Hydrogen peroxide $\left(\mathrm{H}_{2} \mathrm{O}_{2}\right)$ as a strong oxidant, is widely used in various chemical industries and environmental remediation processes. In this study, we developed an innovative method for cost-effective production of $\mathrm{H}_{2} \mathrm{O}_{2}$ by using a microbial reverse-electrodialysis electrolysis cell (MREC). In the MREC, electrical potential generated by the exoelectrogens and the salinity-gradient between salt and fresh water were utilized to drive the high-rate $\mathrm{H}_{2} \mathrm{O}_{2}$ production. Operational parameters such as air flow rate, $\mathrm{pH}$, cathodic potential, flow rate of salt and fresh water were investigated. The optimal $\mathrm{H}_{2} \mathrm{O}_{2}$ production was observed at salt and fresh water flow rate of $0.5 \mathrm{~mL} \mathrm{~min}^{-1}$, air flow rate of $12-20 \mathrm{~mL} \mathrm{~min}^{-1}$, cathode potential of $0.485 \pm 0.025 \mathrm{~V}$ (vs Ag/AgCl). The maximum $\mathrm{H}_{2} \mathrm{O}_{2}$ accumulated concentration of $778 \pm 11$ $\mathrm{mg} \mathrm{L}^{-1}$ was obtained at corresponding production rate of $11.5 \pm 0.5 \mathrm{mg} \mathrm{L}^{-1} \mathrm{~h}^{-1}$. The overall energy input for the synthesis process was $0.45 \pm 0.03 \mathrm{kWh} \mathrm{kg}^{-1} \mathrm{H}_{2} \mathrm{O}_{2}$. Cathode potential was the key factor for $\mathrm{H}_{2} \mathrm{O}_{2}$ production, which was mainly affected by the air flow rate. This work for the first time proved the potential of MREC as an efficient platform technology for simultaneous electrosynthesis of valuable chemicals and utilization of salinity-gradient energy. Keywords: Microbial electrosynthesis; $\mathrm{H}_{2} \mathrm{O}_{2}$; Microbial reverse-electrodialysis electrolysis cell; Salinity gradient; Cathode potential; Wastewater 


\section{Introduction}

$\mathrm{H}_{2} \mathrm{O}_{2}$ is an environmentally friendly oxidant for various industries and environmental treatment processes, such as pulp and paper bleaching, textile applications, detergent applications, municipal wastewater treatment. It is manufactured industrially mainly through the anthraquinone oxidation [1], which is an energy-intensive and unsustainable process. Thus, sustainable and cost-effective methods for $\mathrm{H}_{2} \mathrm{O}_{2}$ production are being pursued [2, 3].

In recent years, microbial electrochemical technologies have gained increasing attention for energy generation, water treatment, bioremediation and chemical synthesis. Among METs, microbial fuel cell (MFC) [4, 5] and microbial electrolysis cell (MEC) [6-9] have been demonstrated as alternative approach to produce $\mathrm{H}_{2} \mathrm{O}_{2}$ through two electrons reduction of $\mathrm{O}_{2}$. The $\mathrm{H}_{2} \mathrm{O}_{2}$ concentration in MFCs was only ranging from 79 to $196 \mathrm{mg} \mathrm{L}^{-1}[4,5]$. Comparatively, the maximum $\mathrm{H}_{2} \mathrm{O}_{2}$ concentration close to $1.3 \mathrm{~g} \mathrm{~L}^{-1}$ was produced in MEC at an applied voltage of $0.5 \mathrm{~V}$ [6]. By using MFC as external power supply, a relatively high $\mathrm{H}_{2} \mathrm{O}_{2}$ concentration of $439 \mathrm{mg} \mathrm{L}^{-1}$ was also achieved in MEC [9]. Thus, in the view of production rate and accumulated concentration, MEC is more efficient over MFC for $\mathrm{H}_{2} \mathrm{O}_{2}$ production [8]. However, the external power supply (in whatever form) required by MEC may add the costs to the synthesis process, especially for long-term operation, and thereby hindering its practical application.

Recently, a novel type of microbial electrochemical technologies called microbial reverseelectrodialysis cell (MRC) or microbial reverse-electrodialysis electrolysis cell (MREC), which combines a reverse electrodialysis cell (RED) with MFC or MEC have been developed to enhance electricity production and wastewater treatment or to drive $\mathrm{H}_{2}$ or $\mathrm{CH}_{4}$ generation [10-15]. MRC and MREC are more effective than traditional MFC and MEC on energy capture $[10,12,16,17]$. Especially the MREC has been proved as an attractive alternative to 
the MEC for $\mathrm{H}_{2}$ generation without external power supply [16]. In this context, MREC could be an alternative technology to MEC for cost-effective and efficient $\mathrm{H}_{2} \mathrm{O}_{2}$ production, which has never been reported before. Therefore, it is meaningful to explore the feasible of $\mathrm{H}_{2} \mathrm{O}_{2}$ production in the MREC.

The performance of MREC is affected significantly by the number of cell pairs and salinity gradients between high concentration salt water ( $\mathrm{HC}$, eg., seawater) and low concentration salt water (LC, eg., fresh water), which are well studied [11, 18]. However, another key challenge of the MREC is that a large amount of seawater and fresh water are required. To make the MREC an economically attractive technology for chemical synthesis (e.g., $\mathrm{H}_{2} \mathrm{O}_{2}$ ), the feasibility of recycling the salt and fresh water for minimizing the water consumption needs to be demonstrated. Besides, control of cathode potential for effective $\mathrm{H}_{2} \mathrm{O}_{2}$ formation could be another challenge, as the MREC is operated without external power supply or potentiostat. Cathode potential has been identified as the key parameter for $\mathrm{H}_{2} \mathrm{O}_{2}$ production in MEC $[8,19]$. In different systems, the $\mathrm{H}_{2} \mathrm{O}_{2}$ concentration and optimal cathode potential might differ greatly. Sim et al. investigated the $\mathrm{H}_{2} \mathrm{O}_{2}$ concentration at cathode potential of -0.4 $\mathrm{V},-0.6 \mathrm{~V},-0.8 \mathrm{~V}$ with $\mathrm{O}_{2}$ provision (aqueous and gaseous $\mathrm{O}_{2}$ ) in $\mathrm{MEC}$, and the maximum $\mathrm{H}_{2} \mathrm{O}_{2}$ concentration was achieved at cathode potential of $-0.4 \mathrm{~V}$ [8]. However, in another MEC study, the maximum $\mathrm{H}_{2} \mathrm{O}_{2}$ concentration only was $39.8 \pm 10.4 \mathrm{mg} \mathrm{L}^{-1}$ at the optimal cathode potential of $-1.4 \mathrm{~V}$ (vs $\mathrm{Ag} / \mathrm{AgCl}$ ) [7]. Thus, the interaction between $\mathrm{H}_{2} \mathrm{O}_{2}$ production and cathode potential in the MREC needs to be investigated.

In this study, we developed and investigated the MREC as an alternative way to produce $\mathrm{H}_{2} \mathrm{O}_{2}$. The influential operating parameters such as air flow rate, initial catholyte $\mathrm{pH}$, synthetic salt and fresh water flow rate and catholyte concentration were investigated. The key limiting factors to the cathode potential were also identified. Furthermore, the recycling 
of salt and fresh water and its impact on $\mathrm{H}_{2} \mathrm{O}_{2}$ production were demonstrated. To the best of our knowledge, this is the first time that the salinity-gradient energy harvested by the MREC was used to drive the $\mathrm{H}_{2} \mathrm{O}_{2}$ synthesis. This work not only demonstrates a novel method for $\mathrm{H}_{2} \mathrm{O}_{2}$ synthesis, but also offers a potential platform technology for sustainable wastewater treatment.

\section{Material and methods}

\subsection{Reactor setup and operation.}

The schematic diagram of the MREC reactor is shown in Fig. 1. As previously described [16]. The MREC consisted of anode chamber and cathode chamber, which were separated by a RED stack. The RED stack comprised five cell pairs, each consisting of a cation exchange membrane (CEM) (CMI 7000, membrane international, NJ) and an anion exchange membrane (AEM) (AMI 7001, membrane international, NJ), with alternately high concentration $\mathrm{NaCl}$ solution $\left(35 \mathrm{~g} \mathrm{~L}^{-1}\right)$ as synthetic salt water and low concentration $\mathrm{NaCl}$ solution $\left(0.35 \mathrm{~g} \mathrm{~L}^{-1}\right)$ as synthetic fresh water flowing in between. Additionally, at the end of the stack next to the cathode, one additional AEM was used as a shielding membrane to close the last cell. The anode was a carbon fiber brush $(5.0 \mathrm{~cm}$ diameter, $5.0 \mathrm{~cm}$ length, Mill-Rose, USA), which was heated to $450{ }^{\circ} \mathrm{C}$ for $30 \mathrm{~min}$ in a muffle furnace before use [20]. The cathode was a graphite plate $(3 \mathrm{~cm} \times 3 \mathrm{~cm}) . \mathrm{Ag} / \mathrm{AgCl}$ electrode $(+0.197 \mathrm{~V}$ vs $\mathrm{SHE})$ as reference electrode was placed $\sim 0.5 \mathrm{~cm}$ apart from the cathode electrode to measure the cathode potential, all the cathode potential reported here were vs. $\mathrm{Ag} / \mathrm{AgCl}$ reference electrode. The carbon fiber brush anode was first enriched with biofilm in a MFC using domestic wastewater collected from primary clarifier (Lyngby Wastewater Treatment Plant, Copenhagen, Denmark) together with acetate sodium $(20 \mathrm{mM})$ as substrate [9], and then transferred into the anode chamber of MREC. The working volume of the anode chamber was 
$100 \mathrm{~mL}(5 \mathrm{~cm} \times 5 \mathrm{~cm} \times 4 \mathrm{~cm})$. In order to avoid substrate limitation on the system performance, the anode chamber was continuously fed with the domestic wastewater amended with acetate sodium $\left(\sim 1.6 \mathrm{~g}-\mathrm{COD} \mathrm{L}^{-1}\right.$ in total $)$ at $50 \mathrm{~mL} \mathrm{~d}^{-1}$. The cathode chamber $(5 \mathrm{~cm} \times 5 \mathrm{~cm} \times 2 \mathrm{~cm})$ was filled with $40 \mathrm{~mL} \mathrm{NaCl}$ solution and operated in batch mode. Prior to a new batch run, the cathode chamber was rinsed three times using $\mathrm{NaCl}$ solution. Air was bubbled into the catholyte continuously using a peristaltic pump at different flow rate as stated later on. Unless otherwise stated, the initial catholyte $\mathrm{pH}$ was $7, \mathrm{NaCl}$ solution was $35 \mathrm{~g}$ $\mathrm{L}^{-1}$, the air flow rate was fixed at $12 \mathrm{~mL} \mathrm{~min}^{-1}, \mathrm{HC}$ and $\mathrm{LC}$ solution flow rate was fixed at 0.5 $\mathrm{mL} \min ^{-1}$. Four control reactors were also setup under the following conditions: Control 1, both $\mathrm{HC}$ and $\mathrm{LC}$ solutions were $0.35 \mathrm{~g} \mathrm{~L}^{-1} \mathrm{NaCl}$ solution; Control 2, open circuit; Control 3, no air flow in cathode chamber; Control 4, no microorganisms on the anode. All experiments were carried out in duplicate at room temperature $\left(22 \pm 2{ }^{\circ} \mathrm{C}\right)$.
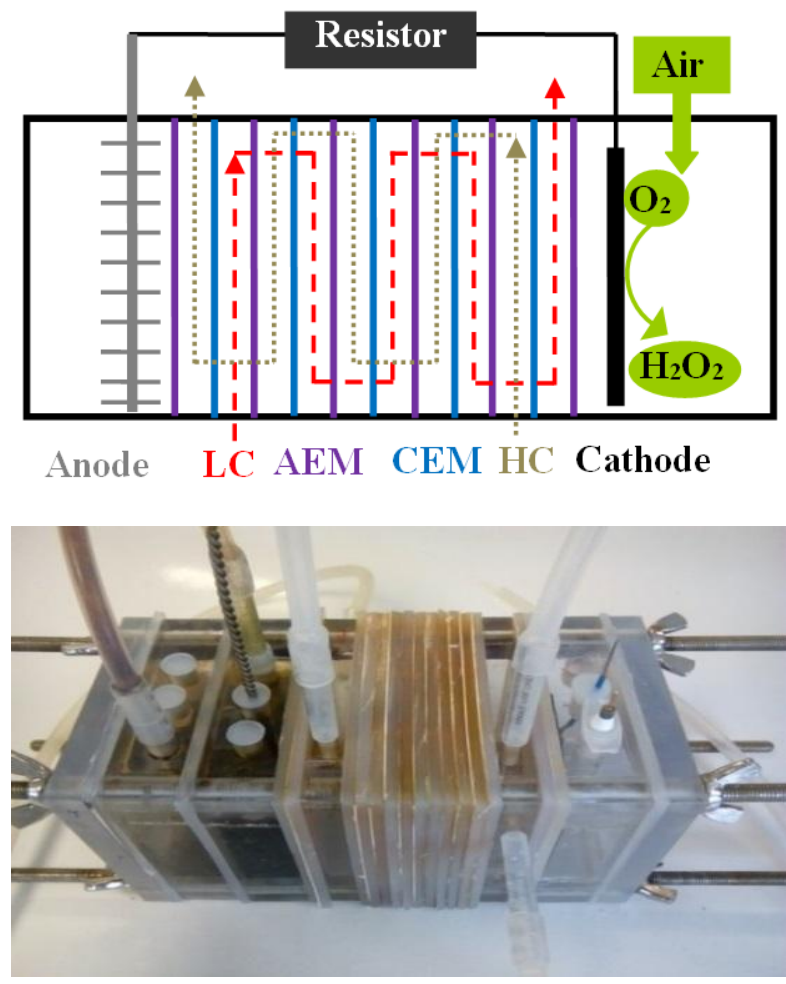

Fig. 1. Schematic of MREC (CEM: cation exchange membrane, AEM: anion exchange membrane, HC: high concentration solution, LC: low concentration solution). 


\subsection{Electrochemical and chemical analysis and calculations.}

The $\mathrm{pH}$ was measured using a $\mathrm{pH}$ meter (PHM $210 \mathrm{pH}$ meter, Radiometer). The $\mathrm{H}_{2} \mathrm{O}_{2}$ concentration was measured by UV-vis spectrophotometry (Spectronic 20D+, Thermo Scientific), using potassium titanium (IV) oxalate as colored indicator [21]. Chemical oxygen demand (COD) was measured according to the Standard Method [22]. The voltage across on one $10 \Omega$ external resistor (load) was monitored with 30 min intervals using a digital multimeter (model 2700, Keithley Instruments, Inc., Cleveland, OH, USA) [23], and the power output was calculated $\left(\mathrm{P}=\mathrm{U}^{2} / \mathrm{R}\right)$.

Coulombic efficiency (CE, \%) was calculated based on total consumption of the COD as previously described [10]. Cathodic $\mathrm{H}_{2} \mathrm{O}_{2}$ efficiency $\left(R_{\text {cat }}\right)$ was defined as the cumulative $\mathrm{H}_{2} \mathrm{O}_{2}$ production actually at the cathode compared to the theoretical amount that could have been produced from the current (based on consuming 2 mol e to produce 1 mole $\mathrm{H}_{2} \mathrm{O}_{2}$ ) [6].

Electrical energy input was defined as the total electrical energy consumption expressed as charge divided by the cumulative $\mathrm{H}_{2} \mathrm{O}_{2}$ production in the MREC system. The electrical energy consumption was measured by a sparometer (Type NZR230, S.L. Energitekinik, Denmark) The calculations of Coulombic efficiency (CE), Cathodic efficiency $\left(R_{c a t}\right)$ and electrical energy input per $\mathrm{kg} \mathrm{H}_{2} \mathrm{O}_{2}$ production are shown in the Supplementary materials.

\section{Results and discussion}

\subsection{The feasibility of $\mathrm{H}_{2} \mathrm{O}_{2}$ production in MREC.}

The evolution of $\mathrm{H}_{2} \mathrm{O}_{2}$ concentration in the MREC is shown in Fig.2. The $\mathrm{H}_{2} \mathrm{O}_{2}$ concentration increased gradually with time and reached around $778 \pm 11 \mathrm{mg} \mathrm{L}^{-1}$ at $72 \mathrm{~h}$ (Fig. 2A). No further increase of $\mathrm{H}_{2} \mathrm{O}_{2}$ was observed with longer operation time, which indicated that the accumulated $\mathrm{H}_{2} \mathrm{O}_{2}$ reached steady state, the same trend also have been reported in MFCs and MECs $[8,24]$. This behavior could be due to that the $\mathrm{H}_{2} \mathrm{O}_{2}$ generation, reduction of $\mathrm{H}_{2} \mathrm{O}_{2}$ on 
the cathode and self-decomposition of $\mathrm{H}_{2} \mathrm{O}_{2}$ might occur simultaneity in the $\mathrm{H}_{2} \mathrm{O}_{2}$ electrogeneration process $[25,26]$. In addition, the $\mathrm{pH}$ increase with the reaction time, which could also promote the $\mathrm{H}_{2} \mathrm{O}_{2}$ self-decomposition in cathode [24]. The $\mathrm{H}_{2} \mathrm{O}_{2}$ production was also investigated under different control conditions. No significant $\mathrm{H}_{2} \mathrm{O}_{2}$ production was observed in the control reactors during the same operation time. The $\mathrm{H}_{2} \mathrm{O}_{2}$ concentration in the reactors without salinity gradient in the RED (HC and LC were in same salt concentration, Control 1), with open circuit (Control 2), without air flow in the catholyte (Control 3) and without microorganisms on the anode (Control 4) was $83 \pm 1.5,0,20.1 \pm 1.9$ and $32.9 \pm 2.8$ $\mathrm{mg} \mathrm{L}^{-1}$, respectively (Fig. 2A).
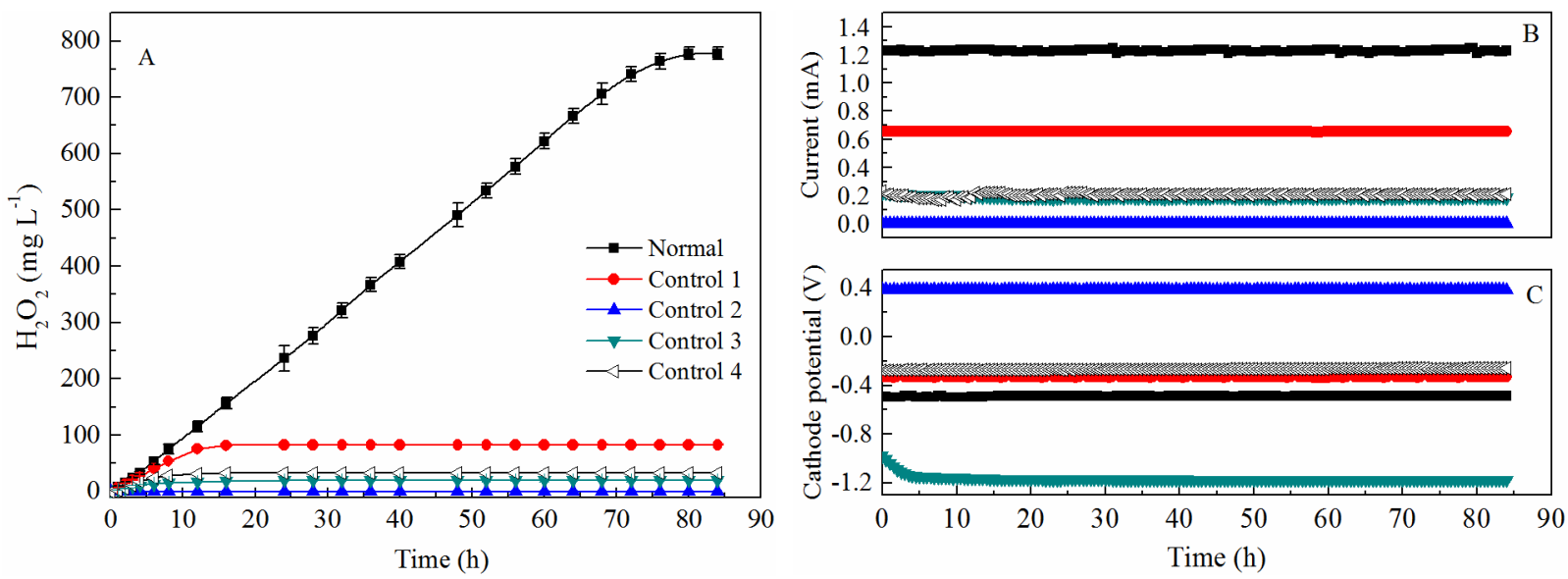

Fig. 2. The performance of MREC under normal and different control conditions (Normal: air flow rate of $12 \mathrm{~mL} \mathrm{~min}^{-1}$, catholyte $\mathrm{pH}$ of $7,0.5 \mathrm{~mL} \mathrm{~min}^{-1} \mathrm{HC}$ and LC solution flow in RED; Control 1 : both $\mathrm{HC}$ and $\mathrm{LC}$ solution are $0.35 \mathrm{~g} \mathrm{~L}^{-1} \mathrm{NaCl}$ solution; Control 2: Open circuit; Control 3: No air flow in cathode chamber; Control 4: No microorganisms on the anode).

Along with $\mathrm{H}_{2} \mathrm{O}_{2}$ production, the current and cathode potential were investigated. As shown in Fig. 2B, the current was very stable and around $1.23 \mathrm{~mA}$ while the cathode potential was $-0.48 \mathrm{~V}$ during $\mathrm{H}_{2} \mathrm{O}_{2}$ production (in Normal Condition). Comparatively, the current observed in all the control reactors were much lower. Unlike current, the cathode potentials were varied in different control reactors. The cathode potential in the reactors with same HC 
and LC flow in the RED (Control 1), with open circuit (Control 2), without air flow in the catholyte (Control 3) and without microorganisms on the anode (Control 4) was about -0.33 , $+0.39,-1.17$ and $-0.27 \mathrm{~V}$, respectively (Fig. 2C). These results demonstrated the RED stack, dissolved oxygen in the catholyte and anodic biofilm are the key factors for $\mathrm{H}_{2} \mathrm{O}_{2}$ generation, which can affect the cathode potential, current and $\mathrm{H}_{2} \mathrm{O}_{2}$ concentration in the MREC.

$\mathrm{H}_{2} \mathrm{O}_{2}$ synthesis and its reduction to water were simultaneously occurring in the cathode. Thus, the maximum $\mathrm{H}_{2} \mathrm{O}_{2}$ concentration that can be reached could be varied in different bioelectrochemical systems, which are important for the further use of the products in commericial applications, such as integration with Fenton reaction for wastewater treatment. The performance of the MREC on $\mathrm{H}_{2} \mathrm{O}_{2}$ production was compared to that of the previously reported METs, as summarized in Table 1. It is obvious that the production concentration of $\mathrm{H}_{2} \mathrm{O}_{2}$ was much higher than that of MFC systems, which was due to the optimal electrical potential generated by the RED stack. The $\mathrm{H}_{2} \mathrm{O}_{2}$ concentration produced by the MREC was comparable to that of the MEC. The $\mathrm{H}_{2} \mathrm{O}_{2}$ concentration observed in this study was even higher than that achieved in a MFC-MEC-coupled system or a MEC with $0.5 \mathrm{~V}$ external voltage supply $[4,27]$. In a recent MEC study, a maximum $\mathrm{H}_{2} \mathrm{O}_{2}$ concentration of $1447 \mathrm{mg} \mathrm{L}^{-}$ ${ }^{1}$ was achieved [8]. Though this value is higher than the one achieved in this study, the advantage of the MREC is obvious as the MEC needs an external power source to supply much higher voltage ranging from 1.24 to $1.69 \mathrm{~V}$ [8], which is not needed for the MREC. 


\begin{tabular}{|c|c|c|c|c|c|c|c|}
\hline METs & Cathode & $\begin{array}{c}\text { External } \\
\text { voltage } \\
\text { (V) }\end{array}$ & $\begin{array}{c}\text { Cathode } \\
\text { potential } \\
(\mathrm{V})\end{array}$ & $\begin{array}{l}\text { Current } \\
\text { density } \\
\left(\mathrm{A} \mathrm{m}^{-2}\right)\end{array}$ & $\begin{array}{c}\mathrm{H}_{2} \mathrm{O}_{2} \\
\text { concentration } \\
\left(\mathrm{mg} \mathrm{L}^{-1}\right)\end{array}$ & $\begin{array}{l}\text { Production rate } \\
\qquad\left(\mu \mathrm{mol} \mathrm{h}{ }^{-1}\right)\end{array}$ & Reference \\
\hline MFC & Graphite & - & - & $18.41^{d}$ & 196.50 & 35.8 & {$[4]$} \\
\hline MFC & Graphite & - & - & $25.40^{\mathrm{d}}$ & 78.20 & - & [27] \\
\hline $\mathrm{MFC}$ & Graphite & - & -0.25 & - & 78.85 & 13.5 & [5] \\
\hline MEC & Graphite & 0.50 & - & $5.30 \pm 0.70$ & $\sim 1300$ & $1596 \pm 163.8$ & [6] \\
\hline MEC & $\begin{array}{l}\text { Graphite with } \\
\text { carbon black }\end{array}$ & 0.60 & - & - & $39.80 \pm 10.40$ & 1.35 & [7] \\
\hline MEC & Graphite & $\mathrm{a}$ & $-1.20 \sim-1.70$ & $7.70 \pm 0.60$ & 1447 & 29.03 & [8] \\
\hline MEC & Graphite & $\mathrm{b}$ & - & 2.40 & 439 & - & [9] \\
\hline MEC & Graphite & $\mathrm{c}$ & - & 2.79 & 700 & - & [28] \\
\hline MEC & Graphite & 0.50 & -0.85 & - & 711.20 & 13.07 & [27] \\
\hline MREC & Graphite & - & -0.48 & $1.37 \pm 0.09$ & $778 \pm 11$ & $13.53 \pm 0.59$ & This study \\
\hline
\end{tabular}

a: control the cathode potential using a potentiostat.

b: one MFC power the MEC

c: control the current by a potentiostat.

$\mathrm{d}$ : current density $\left(\mathrm{A} \mathrm{m}^{-3}\right)$

\subsection{Effect of air flow rate.}

Oxygen is the electron acceptor at the cathode of the MREC, so its availability could be crucial to $\mathrm{H}_{2} \mathrm{O}_{2}$ production. Thus, the effect of air flow rate on $\mathrm{H}_{2} \mathrm{O}_{2}$ production, cathode potential, current and dissolved oxygen (DO) were studied at $\mathrm{HC}$ and $\mathrm{LC}$ flow rate of $0.5 \mathrm{~mL}$ $\min ^{-1}$, initial catholyte $\mathrm{pH}$ of 7 . The results are shown in Fig. 3. The concentration of $\mathrm{H}_{2} \mathrm{O}_{2}$ increased dramatically with the increasing of air flow rate in a certain range, in particular when the air flow rate increasing from 4 to $12 \mathrm{~mL} \mathrm{~min}^{-1}$ (Fig. 3A). The corresponding $\mathrm{H}_{2} \mathrm{O}_{2}$ concentration increased from $19 \pm 2.5$ to $778 \pm 11 \mathrm{mg} \mathrm{L}^{-1}$. When the air flow rate was

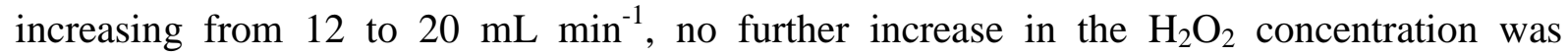
observed. The $\mathrm{H}_{2} \mathrm{O}_{2}$ concentration was kept at $779 \pm 14 \mathrm{mg} \mathrm{L}^{-1}$. However, further increase the air flow rate above $20 \mathrm{~mL} \mathrm{~min}{ }^{-1}$, the $\mathrm{H}_{2} \mathrm{O}_{2}$ concentration decreased significantly. For example, when the air flow rate increased from 20 to $400 \mathrm{~mL} \mathrm{~min}^{-1}$, the $\mathrm{H}_{2} \mathrm{O}_{2}$ concentration decreased from $779 \pm 14$ to $59 \pm 10 \mathrm{mg} \mathrm{L^{-1 }}$. The behavior was similar with that observed in the traditional $\mathrm{H}_{2} \mathrm{O}_{2}$ electrogeneration process [29]. In addition, it also has been reported that the air flow rate could affect the concentration of $\mathrm{H}_{2} \mathrm{O}_{2}$ in dual-chamber MFC reactor [24]. Fig. 
3B shows the trend of DO with the increasing of air flow rate. The DO value increased also with increasing of air flow rate in a certain range. For example, the DO value increased significantly from $5.9 \pm 0.2$ to $8.6 \pm 0.2 \mathrm{mg} \mathrm{L}^{-1}$ with the increase of air flow rate from 4 to 100 $\mathrm{mL} \min ^{-1}$. The DO value maintained at $8.6 \pm 0.2 \mathrm{mg} \mathrm{L}^{-1}$ when the air flow rate was further increased to $400 \mathrm{~mL} \mathrm{~min}^{-1}$. The results indicate that from 12 to $20 \mathrm{~mL} \mathrm{~min}^{-1}$ the oxygen saturation in the cathode was not reached, at the air flow rate over $20 \mathrm{~mL} \mathrm{~min}^{-1}$. The observed decrease of $\mathrm{H}_{2} \mathrm{O}_{2}$ production was due to oxygen saturation that enhanced the further degradation of $\mathrm{H}_{2} \mathrm{O}_{2}$. It is generally considered that a high $\mathrm{O}_{2}$ flow rate is beneficial for $\mathrm{H}_{2} \mathrm{O}_{2}$ generation in electrosythesis system, since high air flow rate could enhance the DO in the solution and promote the mass transfer rate, which is favorable for the $\mathrm{H}_{2} \mathrm{O}_{2}$ accumulation [8, 29]. However, excessive air supply might lead to the stoichometric imbalance of $\mathrm{H}_{2} \mathrm{O}_{2}$ production process (eq.1) [24]. At the same time, the higher air flow rate could also disturb the mass transfer between catholyte and electrode and result in a low catalytic efficiency for $\mathrm{H}_{2} \mathrm{O}_{2}$ generation [21,30]. These results further indicate the importance of air flow rate to the $\mathrm{H}_{2} \mathrm{O}_{2}$ generation in the MREC.
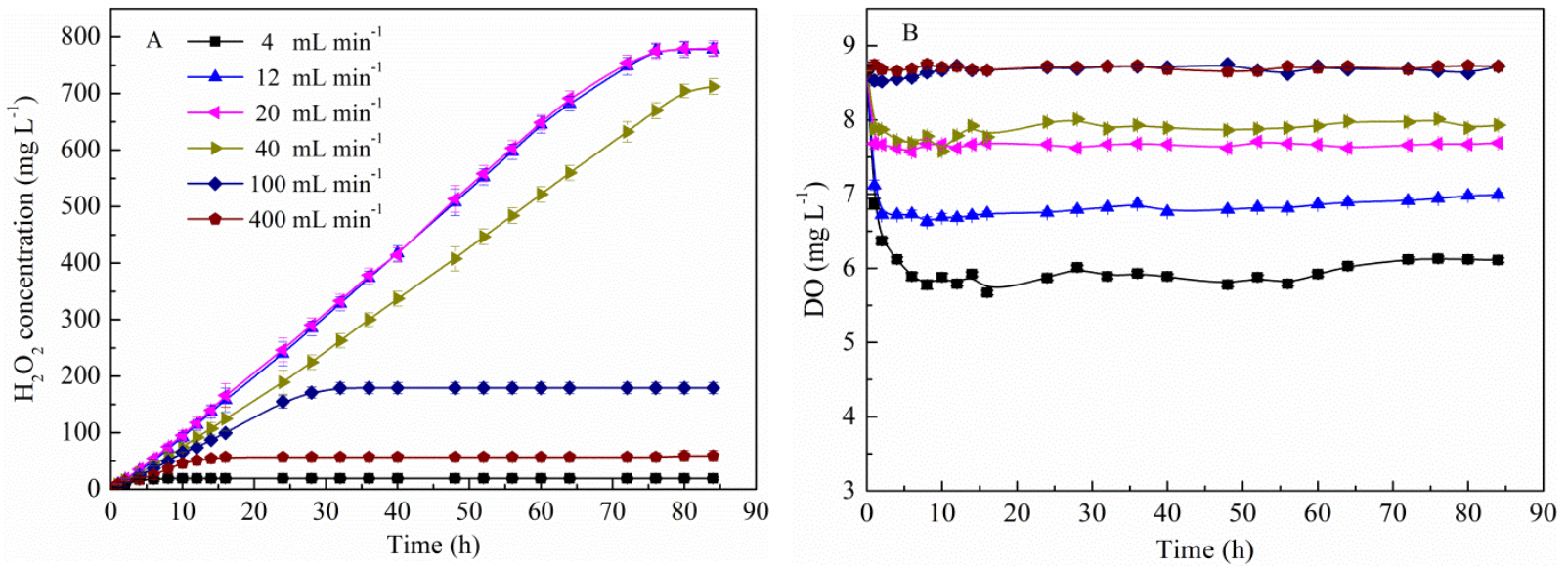

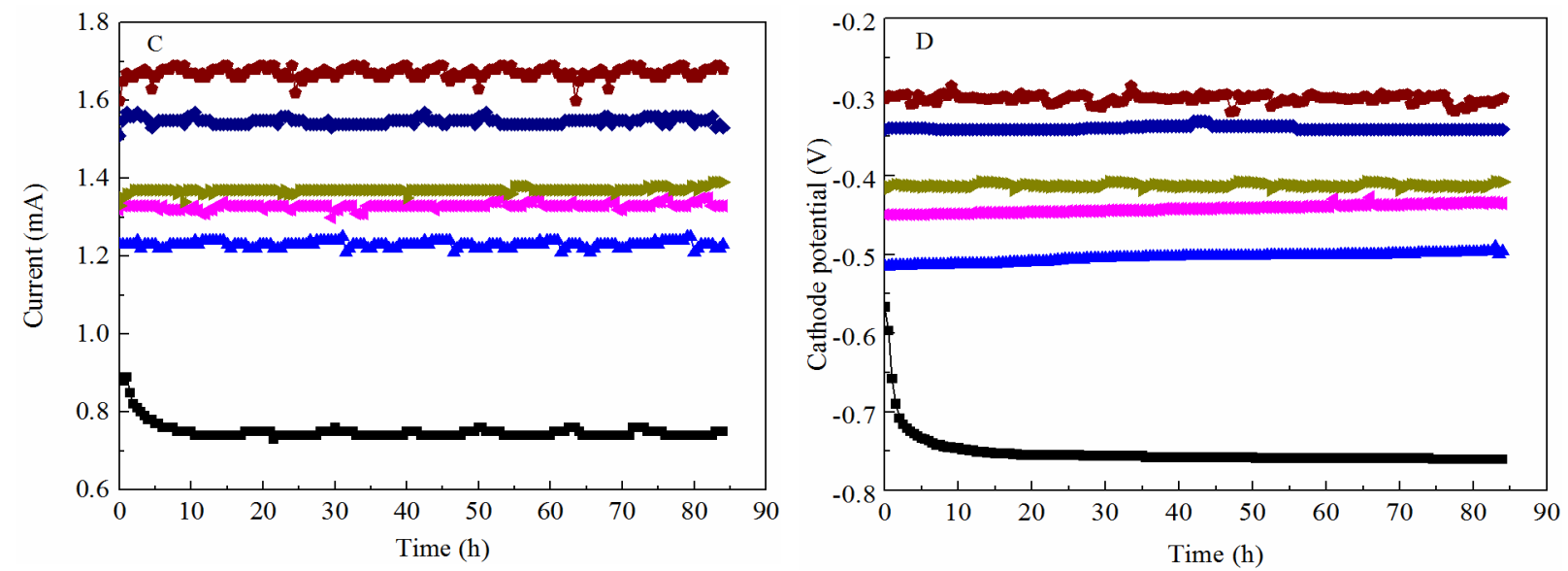

Fig. 3. The effect of air flow rate on the concentration of $\mathrm{H}_{2} \mathrm{O}_{2}(\mathrm{~A})$, DO (B), Current (C) and Cathode potential (D).

It has been previously proved that the cathode potential and current are two key factors for $\mathrm{H}_{2} \mathrm{O}_{2}$ production in METs [8,28]. External power sources or potentiostat can be used to control the cathode potential and current at the suitable value for improving $\mathrm{H}_{2} \mathrm{O}_{2}$ concentration and production rate. In the MREC, the RED stack was placed between the cathode and anode to replace the external power source. In order to further explain the correlations related to the air flow rate, the cathode potential and current output were recorded. Fig. 3C and Fig. 3D show the trend of current and cathode potential in a certain range of air flow rate. Interestingly, when the air flow rate was increased, the corresponding cathode potential became less negative and the current increased significantly. A maximal current of $1.68 \pm 0.03 \mathrm{~mA}$ and cathode potential of $-0.310 \pm 0.05 \mathrm{mV}$ were achieved with the air flow rate of $400 \mathrm{~mL} \mathrm{~min}^{-1}$. However, the maximal $\mathrm{H}_{2} \mathrm{O}_{2}$ concentration was obtained at the air flow rate of 12 to $20 \mathrm{~mL} \mathrm{~min}^{-1}$, the corresponding cathode potential were ranging from $-0.505 \pm$ 0.005 to $-0.442 \pm 0.006 \mathrm{~V}$. The optimal cathode potential for $\mathrm{H}_{2} \mathrm{O}_{2}$ generation was different in different METs (see Table 1). In generally, the two-electron reaction (eq.1), four-electron reaction (eq.2) and the $\mathrm{H}_{2} \mathrm{O}_{2}$ decomposition reaction (eq.3 and 4) occur simultaneously on the surface of cathode [27, 31]. The results indicate that the two-electron reaction (eq. 1) producing $\mathrm{H}_{2} \mathrm{O}_{2}$ was the dominant reaction in the MREC when the air flow rate was 12 to 20 $\mathrm{mL} \min ^{-1}$, because the $\mathrm{H}_{2} \mathrm{O}_{2}$ reduction (eq. 3 and 4) was slower than the $\mathrm{H}_{2} \mathrm{O}_{2}$ formation. Vice-versa, at higher air flow, the lower $\mathrm{H}_{2} \mathrm{O}_{2}$ formation indicates that eq. 2 might dominate. Therefore, the choice of a suitable air flow rate is important for the practical application in the future. 


$$
\begin{array}{ll}
2 \mathrm{H}^{+}+2 \mathrm{e}^{-}+\mathrm{O}_{2} \longrightarrow \mathrm{H}_{2} \mathrm{O}_{2} & \mathrm{E}^{0}=0.475 \mathrm{~V} \text { vs Ag/AgCl } \\
4 \mathrm{H}^{+}+4 \mathrm{e}^{-}+\mathrm{O}_{2} \longrightarrow 2 \mathrm{H}_{2} \mathrm{O} & \mathrm{E}^{0}=1.033 \mathrm{~V} \text { vs Ag/AgCl } \\
\mathrm{H}_{2} \mathrm{O}_{2}+2 \mathrm{e}^{-}+2 \mathrm{H}^{+} \longrightarrow 2 \mathrm{H}_{2} \mathrm{O} & \mathrm{E}^{0}=1.566 \mathrm{~V} \text { vs Ag/AgCl } \\
2 \mathrm{H}_{2} \mathrm{O}_{2} \longrightarrow 2 \mathrm{H}_{2} \mathrm{O}+\mathrm{O}_{2} &
\end{array}
$$

\subsection{Effect of initial catholyte $\mathrm{pH}$.}

The generation of $\mathrm{H}_{2} \mathrm{O}_{2}$ was also carried out at different initial $\mathrm{pH}$ values, during which the changes of $\mathrm{pH}$ values were monitored. The effect of initial catholyte $\mathrm{pH}$ in the MREC was

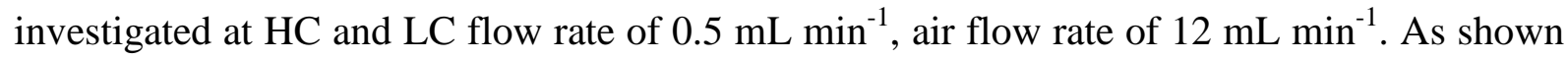
in Fig. 4A, when the initial $\mathrm{pH}$ values were 2, 3, 5, 7 and 10, the $\mathrm{H}_{2} \mathrm{O}_{2}$ concentrations reached to $786 \pm 18,783 \pm 16,779 \pm 15,778 \pm 11$ and $777 \pm 14 \mathrm{mg} \mathrm{L}^{-1}$, respectively. The results indicate that the initial catholyte $\mathrm{pH}$ has no significant effect on the accumulated $\mathrm{H}_{2} \mathrm{O}_{2}$ concentration, which was In agreement with traditional $\mathrm{H}_{2} \mathrm{O}_{2}$ electrogeneration processes [31]. There was a slight decrease of $\mathrm{H}_{2} \mathrm{O}_{2}$ accumulation with the increasing $\mathrm{pH}$ value between 2 and 7 in the first four hours, but no significant difference on the $\mathrm{H}_{2} \mathrm{O}_{2}$ production rate and concentration were observed between $\mathrm{pH} 7$ and $\mathrm{pH} 10$ during the same period. Since $\mathrm{H}_{2} \mathrm{O}_{2}$ was generated on the cathode surface by the reduction of oxygen with $\mathrm{H}^{+}$, a low $\mathrm{pH}$ would be beneficial to increase $\mathrm{H}_{2} \mathrm{O}_{2}$ production rate. That could be the explanation to the relatively higher $\mathrm{H}_{2} \mathrm{O}_{2}$ production rate at low $\mathrm{pH}$ in the first few hours.

The variation trend of the catholyte $\mathrm{pH}$ is shown in Fig. 4B. When the initial $\mathrm{pH}$ values were 3,5 and 7 , the $\mathrm{pH}$ rapidly becomes alkaline after $1 \mathrm{~h}$, while it took 3 hours when the initial $\mathrm{pH}$ was 2 . The final catholyte $\mathrm{pH}$ increase to $\sim 12.5$ regardless of the initial $\mathrm{pH}$. This observation is similar with previous MREC studies focusing on electrical energy production [10]. When the cathode $\mathrm{pH}$ turned to alkaline condition, there were no significant difference on the $\mathrm{H}_{2} \mathrm{O}_{2}$ production rate and concentration. The results explained why the $\mathrm{H}_{2} \mathrm{O}_{2}$ 
production rate turned to be similar after a few hours. The results also demonstrated that the $\mathrm{H}_{2} \mathrm{O}_{2}$ production in the cathode of the MREC was possible both in acidic and alkaline conditions, which was consistent with the observation in the abiotic electrochemical processes for $\mathrm{H}_{2} \mathrm{O}_{2}$ production (eq.1, eq.5 and eq.6) [2]. Thus, $\mathrm{pH}$ adjustment in the cathode could be omitted, which may reduce the costs in the practical application. The above results indicate the unique advantages of the MREC for $\mathrm{H}_{2} \mathrm{O}_{2}$ synthesis in a wide range of $\mathrm{pH}$ values. Acid solutions:

$$
2 \mathrm{H}^{+}+2 \mathrm{e}^{-}+\mathrm{O}_{2} \longrightarrow \mathrm{H}_{2} \mathrm{O}_{2}
$$

Neutral and Alkaline solutions:

$$
\begin{aligned}
& \mathrm{H}_{2} \mathrm{O}+2 \mathrm{e}^{-}+\mathrm{O}_{2} \longrightarrow \mathrm{HO}_{2}^{-}+\mathrm{OH}^{-} \\
& \mathrm{HO}_{2}^{-}+\mathrm{H}_{2} \mathrm{O} \longrightarrow \mathrm{H}_{2} \mathrm{O}_{2}+\mathrm{OH}^{-}
\end{aligned}
$$

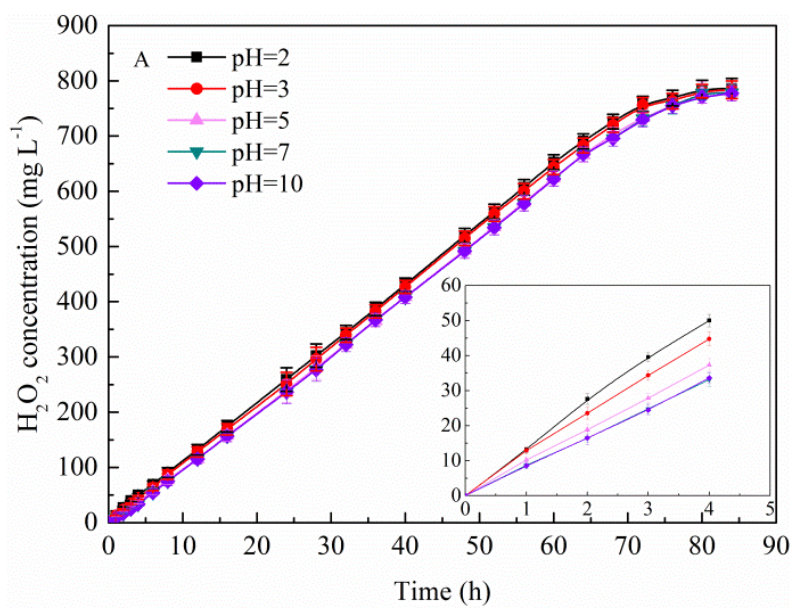

Fig. 4. The effect of initial $\mathrm{pH}$ on the $\mathrm{H}_{2} \mathrm{O}_{2}$ production in the MREC.

\subsection{Effect of HC and LC solution flow rate.}

The performance of $\mathrm{H}_{2} \mathrm{O}_{2}$ production was investigated with the flow rates of the $\mathrm{HC}$ and $\mathrm{LC}$ solutions ranging from 0.2 to $6 \mathrm{~mL} \mathrm{~min}^{-1}$. As shown in Fig. 5A, an increase in flow rate from 0.2 to $0.5 \mathrm{~mL} \mathrm{~min}^{-1}$ resulted in a significant increase in the $\mathrm{H}_{2} \mathrm{O}_{2}$ concentration and production rate. When the flow rate increased from 0.5 to $2 \mathrm{~mL} \mathrm{~min}^{-1}$, the $\mathrm{H}_{2} \mathrm{O}_{2}$ concentration and 
production rate were maintain at maximum values of $778 \pm 11 \mathrm{mg} \mathrm{L}^{-1}$ and $11.5 \pm 0.5 \mathrm{mg} \mathrm{L}^{-1}$ $\mathrm{h}^{-1}$ (Fig. 5A). Further increase the flow rate to $6 \mathrm{~mL} \mathrm{~min}^{-1}$, there was no significant changes of $\mathrm{H}_{2} \mathrm{O}_{2}$ concentration. However, there was a small decrease in the $\mathrm{H}_{2} \mathrm{O}_{2}$ production rate. The electrical output can be improved through increasing the solution flow rate within a certain range in RED, and then a relatively high current is beneficial to the $\mathrm{H}_{2} \mathrm{O}_{2}$ production. However, higher flow rates also lead to high ohmic losses, as there was no enough time to complete the ion transportation through membranes which maintained the influent LC and $\mathrm{HC}$ salinity throughout the RED $[10,33]$. Thus, a small decrease of the current and the production rate were observed at the flow rate of $6 \mathrm{~mL} \mathrm{~min}^{-1}$. Consistent with the current, the cathode potential was varied in the range of -0.5 to $-0.4 \mathrm{~V}$ at different solution flow rates (Fig. 5B). With respect to the maximum $\mathrm{H}_{2} \mathrm{O}_{2}$ concentration and production rate, the cathode potential was maintained at $0.45 \pm 0.04 \mathrm{~V}$ at the solution flow rate of $0.5 \mathrm{~mL} \mathrm{~min}^{-1}$.
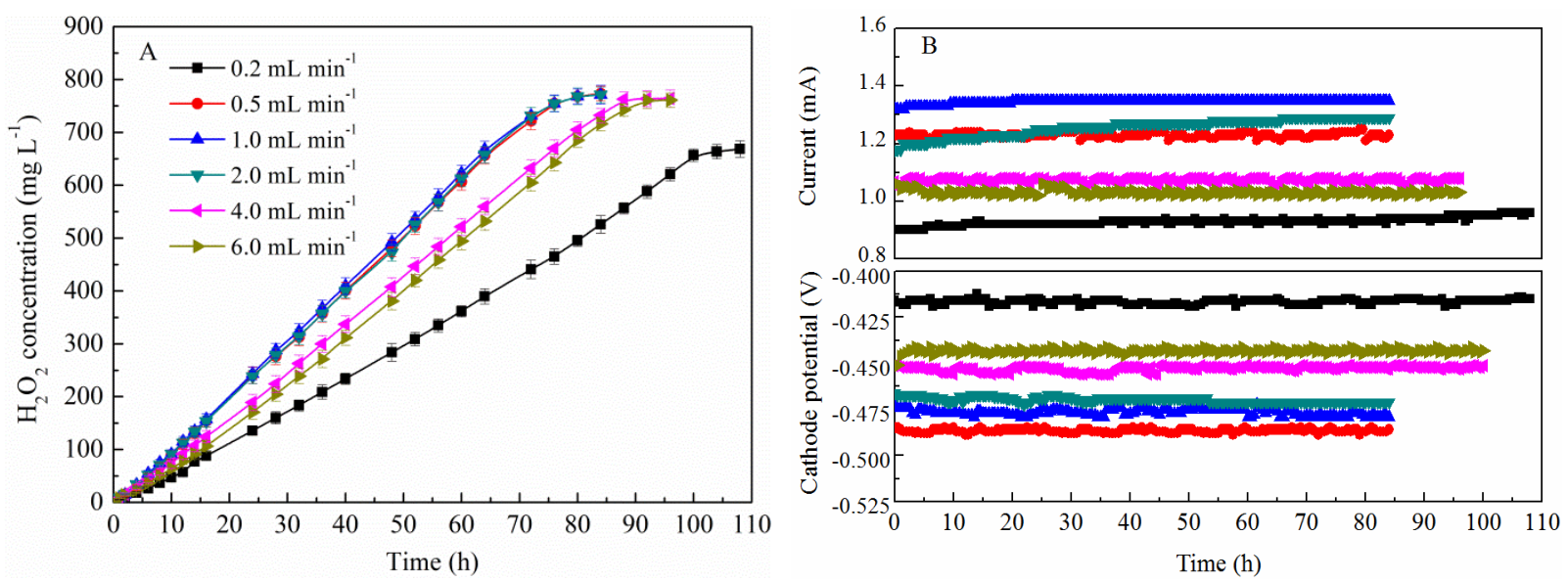

Fig. 5. The effect of $\mathrm{HC}$ and $\mathrm{LC}$ flow rate on the $\mathrm{H}_{2} \mathrm{O}_{2}$ production.

The flow rate not only impacted the $\mathrm{H}_{2} \mathrm{O}_{2}$ production, but also affected the energy required to pump the $\mathrm{HC}$ and LC solutions through the RED stack. The pumping energy is an important part of the costs for RED operation, and thus, a low flow rate is preferred for practical applications [34]. In order to obtain maximum $\mathrm{H}_{2} \mathrm{O}_{2}$ concentration with minimum 
energy costs for MREC operation, the optimum flow rate was considered to be $0.5 \mathrm{~mL} \mathrm{~min}{ }^{-1}$ based on the above results (Fig. 5A).

\subsection{Performance with recycling HC and LC solution.}

A commercial MREC installation should aim at high concentration of $\mathrm{H}_{2} \mathrm{O}_{2}$ production with low water consumption in a certain range. In order to further reduce the energy cost and water consumption, the recyclability of the $\mathrm{HC}$ and $\mathrm{LC}$ solution were investigated at $0.5 \mathrm{~mL} \mathrm{~min}{ }^{-1}$ flow rate. As shown in Fig. 6A, the concentration of LC increased with the increasing of recycle time, while the concentration of $\mathrm{HC}$ showed opposite trend. Thus, the salinity ratios became smaller and smaller, eg., after 13 cycles, the salinity ratio between HC and LC solution decreased from 100 to 2.5 . The $\mathrm{H}_{2} \mathrm{O}_{2}$ concentration was maintained at $778 \pm 11 \mathrm{mg}$ $\mathrm{L}^{-1}$ during the first 9 cycles. When the $\mathrm{HC}$ and $\mathrm{LC}$ were recycled after 9 cycles, the $\mathrm{H}_{2} \mathrm{O}_{2}$ concentration and current started to decrease (Fig. 6B), while the cathode potential began to increase. A possible explanation could be that the decreasing of salinity ratio decreased electrochemical junction potential in the RED stack [12], and then resulting in the change of cathode potential. The behavior is similar with the $\mathrm{H}_{2}$ production in MREC.
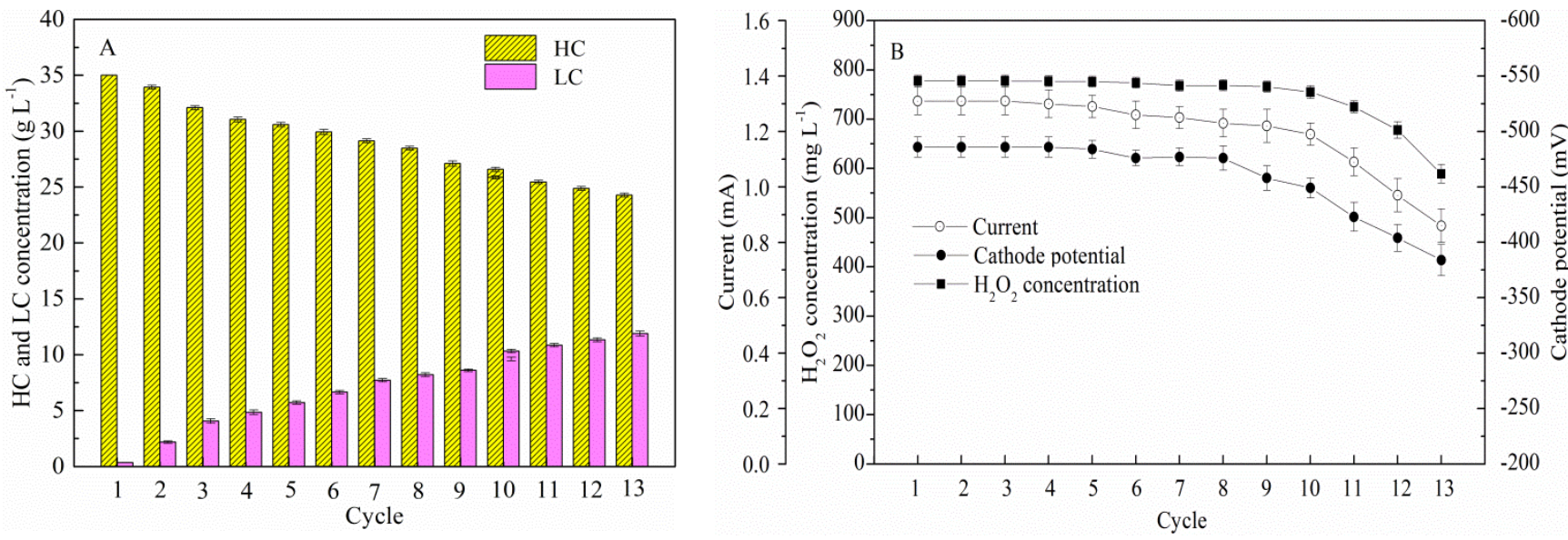

Fig. 6. The effect of $\mathrm{HC}$ and $\mathrm{LC}$ concentration on $\mathrm{H}_{2} \mathrm{O}_{2}$ generation. 
During each cycle, the anolyte $\mathrm{pH}$ was maintained at neutral (data is not shown) under continuous flow mode, which exclude the inhibition of anodic biofilm caused by anolyte $\mathrm{pH}$ $[10,35]$. The COD removal efficiency was above $85 \%$ in all these cycles (data is not shown). These results for the first time demonstrated the feasibility of simultaneously recyling the HC and LC solutions in MREC, especially for $\mathrm{H}_{2} \mathrm{O}_{2}$ production, which offer insight on scaling up the technology with less water consumption. Furthermore, the results also indicate the applicability of MREC with broad salinity ratios between HC and LC solution without deteriorating the system performance on $\mathrm{H}_{2} \mathrm{O}_{2}$ production.

\subsection{Effect of catholyte concentration.}

The power density of RED can be increased upon increasing the concentration of electrolyte [36]. To investigate the effect of catholyte concentration on $\mathrm{H}_{2} \mathrm{O}_{2}$ generation, the experiments were carried out with initial cathode $\mathrm{pH}$ of 7, air flow rate of $12 \mathrm{~mL} \mathrm{~min}^{-1}$ and $\mathrm{HC}$ and $\mathrm{LC}$ flow rate of $0.5 \mathrm{~mL} \mathrm{~min}{ }^{-1}$. As shown in Fig. 7, the catholyte concentration had significant impact on the $\mathrm{H}_{2} \mathrm{O}_{2}$ production. The $\mathrm{H}_{2} \mathrm{O}_{2}$ concentration increased from $45 \pm 10$ to $778 \pm 11$ $\mathrm{mg} \mathrm{L}{ }^{-1}$ with the increasing of $\mathrm{NaCl}$ concentration from 0 to $21 \mathrm{~g} \mathrm{~L}^{-1}$, when further increase the concentration to $35 \mathrm{~g} \mathrm{~L}^{-1}$, no increase on $\mathrm{H}_{2} \mathrm{O}_{2}$ concentration were observed. This result also suggests that the $\mathrm{H}_{2} \mathrm{O}_{2}$ could be produced by using deionized water as catholyte, although the final $\mathrm{H}_{2} \mathrm{O}_{2}$ concentration is low. The catholyte concentration also influenced the current, eg., the current increased significantly from $0.76 \pm 0.03$ to $1.29 \pm 0.08 \mathrm{~mA}$ with the increasing of catholyte concentration from 0 to $21 \mathrm{~g} \mathrm{~L}^{-1}$. Further increase the concentration to $35 \mathrm{~g} \mathrm{~L}^{-1}$, the current value had no appreciable change. The observation could be due to that the catholyte conductivity and ionic strength increased with the increasing of catholyte concentration and thereby improving the current and $\mathrm{H}_{2} \mathrm{O}_{2}$ concentration. However, the improvement on the current turned to be steady-state when the catholyte concentration excessed a certain range. 


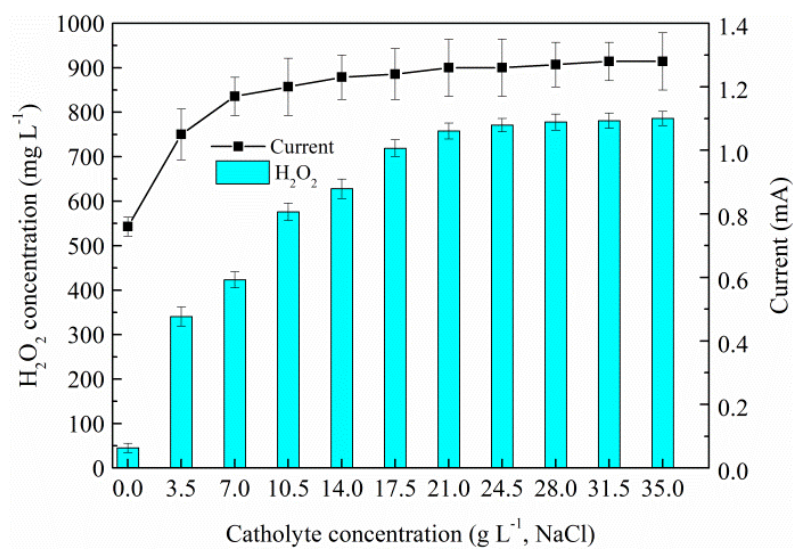

Fig. 7. The effect of catholyte concentration on $\mathrm{H}_{2} \mathrm{O}_{2}$ generation.

\subsection{Energy consumption and efficiency}

In the light of $\mathrm{H}_{2} \mathrm{O}_{2}$ concentration and the energy consumption, the $\mathrm{HC}$ and $\mathrm{LC}$ flow rate of $0.5 \mathrm{~mL} \mathrm{~min}^{-1}$ and air flow rate of $12 \mathrm{~mL} \mathrm{~min}^{-1}$ are the optimal choice for the $\mathrm{H}_{2} \mathrm{O}_{2}$ production in this MREC system, the energy input $\left(0.45 \pm 0.03 \mathrm{kWh} \mathrm{kg}^{-1} \mathrm{H}_{2} \mathrm{O}_{2}\right)$ was significantly lower than that of MEC systems for $\mathrm{H}_{2} \mathrm{O}_{2}$ production, which require about $0.66 \sim 0.93 \mathrm{kWh} \mathrm{kg}^{-1}$ $\mathrm{H}_{2} \mathrm{O}_{2}[6,27]$. In addition, the $\mathrm{H}_{2} \mathrm{O}_{2}$ production cost is lower than the price of commercial bulk $\mathrm{H}_{2} \mathrm{O}_{2}$ which is about 1.5 \$ per $\mathrm{kg} \mathrm{H}_{2} \mathrm{O}_{2}$ [32]. The coulombic efficiency was only $14.96 \pm$ $0.86 \%$, while the COD removal reached $86.25 \pm 0.75 \%$ in the anode fed with real wastewater. Power output of the MREC was stable at $15.13 \pm 0.25 \mu \mathrm{W}$ (see Fig.S1, Supplementary data). The low CE could be due to the oxidation of organic matters by the nonexoelectrogenic microorganisms from wastewater. The cathodic efficiency was $53.26 \pm 0.68 \%$, which is better than previous reports of $42 \%$ [32]. Moreover, the synthesized water through oxygen reduction reaction only was $0.0067 \pm 0.0005 \mathrm{~mL}$, it is not significant. Despite the cumulative $\mathrm{H}_{2} \mathrm{O}_{2}$ production in the MREC system still is low for large-scale industrial application, the rather low energy cost for $\mathrm{H}_{2} \mathrm{O}_{2}$ production still makes the technology very promising. Table 2 summarizes energy consumption under eight different conditions. 


\begin{tabular}{cccccc}
\hline $\begin{array}{c}\text { Air flow rate } \\
\left(\mathrm{mL} \mathrm{min}^{-1}\right)\end{array}$ & $\begin{array}{c}\mathrm{HC} \text { and LC flow rate } \\
\left(\mathrm{mL} \mathrm{min}^{-1}\right)\end{array}$ & $\begin{array}{c}\text { Anolyte COD } \\
\text { removal }(\%)\end{array}$ & $\begin{array}{c}R_{\text {cat }} \\
(\%)\end{array}$ & $\begin{array}{c}\text { Energy input } \\
\left(\mathrm{kWh} \mathrm{kg}^{-1} \mathrm{H}_{2} \mathrm{O}_{2}\right)\end{array}$ & $\begin{array}{c}\mathrm{CE} \\
(\%)\end{array}$ \\
\hline 12 & 0.5 & $86.25 \pm 0.75$ & $53.26 \pm 0.68$ & $0.45 \pm 0.03$ & $14.96 \pm 0.86$ \\
20 & 0.5 & $85.64 \pm 0.65$ & $49.65 \pm 0.56$ & $0.54 \pm 0.03$ & $15.49 \pm 0.58$ \\
40 & 0.5 & $86.47 \pm 0.53$ & $42.58 \pm 0.42$ & $0.62 \pm 0.02$ & $15.53 \pm 0.67$ \\
12 & 0.2 & $86.35 \pm 0.36$ & $41.98 \pm 0.44$ & $0.49 \pm 0.04$ & $11.56 \pm 0.87$ \\
12 & 1.0 & $86.53 \pm 0.86$ & $47.49 \pm 0.31$ & $0.48 \pm 0.04$ & $14.97 \pm 0.49$ \\
12 & 2.0 & $85.64 \pm 0.76$ & $49.32 \pm 0.29$ & $0.48 \pm 0.03$ & $14.18 \pm 0.76$ \\
12 & 4.0 & $84.54 \pm 0.72$ & $51.25 \pm 0.45$ & $0.51 \pm 0.03$ & $12.44 \pm 0.97$ \\
12 & 6.0 & $84.63 \pm 0.46$ & $51.45 \pm 0.66$ & $0.51 \pm 0.03$ & $12.35 \pm 0.85$ \\
\hline
\end{tabular}

\subsection{Significance and perspectives}

The present work for the first time demonstrated the applicability of the MERC for $\mathrm{H}_{2} \mathrm{O}_{2}$ production. Compared to other microbial electrochemical systems such as MFC and MEC, MREC has its own merits. Firstly, the $\mathrm{H}_{2} \mathrm{O}_{2}$ production was greatly improved by employing the RED stacks between the anode and cathode, compared to the MFC. Secondly, no external power source is needed as the potential created by the RED stacks reactor can accelerate the electron transfer for cathode reduction, compared to the MEC. Thirdly, the energy consumption was only $0.45 \pm 0.03 \mathrm{kWh} \mathrm{kg}^{-1} \mathrm{H}_{2} \mathrm{O}_{2}$ under optimal operation condition, which indicated that the MREC is an energy-efficient system for synthesis of $\mathrm{H}_{2} \mathrm{O}_{2}$.

Though promising, more efforts should be made to accelerate the industrial application. First of all, the $\mathrm{H}_{2} \mathrm{O}_{2}$ concentration still needs to be improved to the level which meets the industrial implications. The volume of $\mathrm{H}_{2} \mathrm{O}_{2}$ generated in present study was insignificant (less than $0.1 \mathrm{ml}$ ) compared to the catholyte volume $(40 \mathrm{ml})$ (Table S1). To obtain pure or high $\mathrm{H}_{2} \mathrm{O}_{2}$ concentration and simultaneous to save the energy for product separation, a moist opento air cathode could be used $[37,38]$. Secondly, this is a proof-of-concept study, while a more cost-effective and efficient reactor configuration needs to be developed for the field application. For instance, single porous ceramic membrane that can more easily serve the purpose of driving the electro-osmosis and remove the need for a whole bunch of synthetic 
membranes could be interesting for future studies on system optimization. Thirdly, to further consolidate the in-situ utilization of the produced $\mathrm{H}_{2} \mathrm{O}_{2}$, it would be interesting to integrate the MREC with various environmental bioremediation processes such as advance oxidation processes for water treatment. In addition, it could be also interesting to use high salt feedstock in the anodic chamber in future studies as there were some electrochemically active bacteria that can grow naturally in sea water, urine and other salty environments [39, 40]. All these together will make MREC an attractive platform technology for the electrosynthesis of $\mathrm{H}_{2} \mathrm{O}_{2}$ and potentially utilization of salinity-gradient energy.

\section{Conclusions}

In this study, the MREC system was for the first time developed for microbial electrosynthesis of $\mathrm{H}_{2} \mathrm{O}_{2}$ from oxygen reduction. High $\mathrm{H}_{2} \mathrm{O}_{2}$ concentration of $778 \pm 11 \mathrm{mg} \mathrm{L}^{-1}$ was obtained without utilizing any external power source. The cathode potential as the key factor for $\mathrm{H}_{2} \mathrm{O}_{2}$ electrosynthesis was affected by the air flow rate. In addition, the $\mathrm{H}_{2} \mathrm{O}_{2}$ production was affected by catholyte concentration. Moreover, it showed a good performance for the electrochemical reduction of $\mathrm{O}_{2}$ to $\mathrm{H}_{2} \mathrm{O}_{2}$ in a wide range of $\mathrm{pH}(2-10)$. Furthermore, no deterioration in $\mathrm{H}_{2} \mathrm{O}_{2}$ production was observed by recycling the salt and fresh water in the first 9 cycles. The energy costs for the $\mathrm{H}_{2} \mathrm{O}_{2}$ synthesis using MREC was as low as $0.45 \pm 0.03$ $\mathrm{kWh} \mathrm{kg}^{-1} \mathrm{H}_{2} \mathrm{O}_{2}$. All these features indicate that MREC is an attractive method for the electrosynthesis of $\mathrm{H}_{2} \mathrm{O}_{2}$.

\section{Acknowledgments}

The authors would like to acknowledge financial support from the China Scholarship Council and the technical assistance by Hector Gracia with analytical measurements. This research was supported financially by The Danish Council for Independent Research (DFF-133500142). 


\section{References}

[1] J.M. Campos-Martin, G. Blanco-Brieva, J.L. Fierro, Hydrogen Peroxide Synthesis: An Outlook beyond the Anthraquinone Process, Angew. Chem. Int. Ed. 45 (2006) 6962-6984.

[2] Y. Liu, X. Quan, X. Fan, H. Wang, S. Chen, High-Yield Electrosynthesis of Hydrogen Peroxide from Oxygen Reduction by Hierarchically Porous Carbon, Angew. Chem. Int. Ed. 54 (2015) $6837-6841$.

[3] Y. Yi, L. Wang, G. Li, H. Guo, A review on research progress in the direct synthesis of hydrogen peroxide from hydrogen and oxygen: noble-metal catalytic method, fuel-cell method and plasma method, Catal. Sci. Technol. (2016). DOI:10.1039/c5cy01567g.

[4] J. Y. Chen, N. Li, L. Zhao, Three-dimensional electrode microbial fuel cell for hydrogen peroxide synthesis coupled to wastewater treatment, J. Power Sources 254 (2014) 316-322.

[5] L. Fu, S. J. You, F. 1. Yang, M.-m. Gao, X.-h. Fang, G.-q. Zhang, Synthesis of hydrogen peroxide in microbial fuel cell, J. Chem. Technol. Biotechnol. 85 (2010) 715-719.

[6] R.A. Rozendal, E. Leone, J. Keller, K. Rabaey, Efficient hydrogen peroxide generation from organic matter in a bioelectrochemical system, Electrochem. Commun. 11 (2009) 1752-1755.

[7] N. Li, J. An, L. Zhou, T. Li, J. Li, C. Feng, X. Wang, A novel carbon black graphite hybrid aircathode for efficient hydrogen peroxide production in bioelectrochemical systems, J. Power Sources 306 (2016) 495-502.

[8] J. Sim, J. An, E. Elbeshbishy, H. Ryu, H.S. Lee, Characterization and optimization of cathodic conditions for $\mathrm{H}_{2} \mathrm{O}_{2}$ synthesis in microbial electrochemical cells, Bioresour. Technol. 195 (2015) $31-36$

[9] Y. Zhang, Y. Wang, I. Angelidaki, Alternate switching between microbial fuel cell and microbial electrolysis cell operation as a new method to control $\mathrm{H}_{2} \mathrm{O}_{2}$ level in Bioelectro-Fenton system, J. Power Sources 291 (2015) 108-116.

[10] Y. Kim, B.E. Logan, Microbial reverse electrodialysis cells for synergistically enhanced power production, Environ. Sci. Technol. 45 (2011) 5834-5839. 
[11] X. Luo, J.Y. Nam, F. Zhang, X. Zhang, P. Liang, X. Huang, B.E. Logan, Optimization of membrane stack configuration for efficient hydrogen production in microbial reverseelectrodialysis electrolysis cells coupled with thermolytic solutions, Bioresour. Technol. 140 (2013) 399-405.

[12] J.Y. Nam, R.D. Cusick, Y. Kim, B.E. Logan, Hydrogen generation in microbial reverseelectrodialysis electrolysis cells using a heat-regenerated salt solution, Environ. Sci. Technol. 46 (2012) 5240-5246.

[13] V.J. Watson, M. Hatzell, B.E. Logan, Hydrogen production from continuous flow, microbial reverse-electrodialysis electrolysis cells treating fermentation wastewater, Bioresour. Technol. 195 (2015) 51-56.

[14] X. Luo, F. Zhang, J. Liu, X. Zhang, X. Huang, B.E. Logan, Methane production in microbial reverse-electrodialysis methanogenesis cells (MRMCs) using thermolytic solutions, Environ. Sci. Technol. 48 (2014) 8911-8918.

[15] A. D’Angelo, A. Galia, O. Scialdone, Cathodic abatement of Cr(VI) in water by microbial reverse-electrodialysis cells, J. Electroanal. Chem. 748 (2015) 40-46.

[16] Y. Kim, B.E. Logan, Hydrogen production from inexhaustible supplies of fresh and salt water using microbial reverse-electrodialysis electrolysis cells, Proc. Natl. Acad. Sci. 108 (2011) 16176-16181.

[17] R.D. Cusick, K. Younggy, B.E. Logan, Energy Capture from Thermolytic Solutions in Microbial Reverse-Electrodialysis Cells, Science 335 (2012) 1474-1477.

[18] X. Zhu, W. He, B.E. Logan, Influence of solution concentration and salt types on the performance of reverse electrodialysis cells, J. Membr. Sci. 494 (2015) 154-160.

[19] O. Modin, K. Fukushi, Development and testing of bioelectrochemical reactors converting wastewater organics into hydrogen peroxide, Water Sci. Technol. 66 (2012) 831-836.

[20] Y. Zhang, I. Angelidaki, Recovery of ammonia and sulfate from waste streams and bioenergy production via bipolar bioelectrodialysis, Water Res. 85 (2015) 177-184. 
[21] Sellers RM. Spectrophotometric determination of hydrogen peroxide using potassium titanium (IV) oxalate. Analyst. 105 (1980) 950-954.

[22] A.W.W.A, American Public Health Association, Water Pollution Control Federation, Standard Methods for the Examination of Water and Wastewater, Washington, DC, (1998).

[23] Y. Zhang, L.G. Olias, P. Kongjan, I. Angelidaki, Submersible microbial fuel cell for electricity production from sewage sludge, Water Sci. Technol. 64 (2011) 50-55.

[24] T. Ling, B. Huang, M. Zhao, Q. Yan, W. Shen, Repeated oxidative degradation of methyl orange through bio-electro-Fenton in bioelectrochemical system (BES), Bioresour. Technol. 203 (2016) 89-95.

[25] Z. Qiang, J. H. Chang, C. P. Huang, Electrochemical generation of hydrogen peroxide from dissolved oxygen in acidic solutions, Water Res. 36 (2002) 85-94.

[26] G. Xia, Y. Lu, H. Xu, An energy-saving production of hydrogen peroxide via oxygen reduction for electro-Fenton using electrochemically modified polyacrylonitrilebased carbon fiber brush cathode, Sep. Purif. Technol. 156 (2015) 553-560.

[27] J. y. Chen, L. Zhao, N. Li, H. Liu, A microbial fuel cell with the three-dimensional electrode applied an external voltage for synthesis of hydrogen peroxide from organic matter, J. Power Sources 287 (2015) 291-296.

[28] O. Modin, K. Fukushi, Production of high concentrations of $\mathrm{H}_{2} \mathrm{O}_{2}$ in a bioelectrochemical reactor fed with real municipal wastewater, Environ.Technol. 34 (2013) 2737-2742.

[29] L. Zhou, Z. Hu, C. Zhang, Z. Bi, T. Jin, M. Zhou, Electrogeneration of hydrogen peroxide for electro-Fenton system by oxygen reduction using chemically modified graphite felt cathode, Sep. Purif. Technol. 111 (2013) 131-136.

[30] H. Luo, C. Li, C. Wu, X. Dong, In situ electrosynthesis of hydrogen peroxide with an improved gas diffusion cathode by rolling carbon black and PTFE, RSC Adv. 5 (2015) 65227-65235.

[31] E. Brilla, M. A. Oturan, Electro-Fenton Process and Related Electrochemical Technologies Based on Fenton's Reaction Chemistry, Chem. Rev. 109 (2009) 6570-6631. 
[32] G. Gao, Q. Zhang, Z. Hao, C.D. Vecitis, Carbon Nanotube Membrane Stack for Flow-through Sequential Regenerative Electro-Fenton, Environ. Sci. Technol. 49 (2015) 2375-2383.

[33] D.A. Vermaas, M. Saakes, K. Nijmeijer, Doubled power density from salinity gradients at reduced intermembrane distance, Environ. Sci. Technol. 45 (2011) 7089-7095.

[34] X. Zhu, W. He, B.E. Logan, Reducing pumping energy by using different flow rates of high and low concentration solutions in reverse electrodialysis cells. J. Membr. Sci. 486 (2015) 215-221.

[35] B. Zhang, Z. Wang, X. Zhou, C. Shi, H. Guo, C. Feng, Electrochemical decolorization of methyl orange powered by bioelectricity from single-chamber microbial fuel cells, Bioresour. Technol. 181 (2015) 360-362.

[36] O. Scialdone, A. Galia, C. Gattuso, S. Sabatino, B. Schiavo, Effect of air pressure on the electro-generation of $\mathrm{H}_{2} \mathrm{O}_{2}$ and the abatement of organic pollutants in water by electro-Fenton process, Electrochim. Acta 182 (2015) 775-780.

[37] I. Gajda, J. Greenman, C. Melhuish, C. Santoro, B. Li, P. Cristiani, I. Ieropoulos, Electroosmotic-based catholyte production by Microbial Fuel Cells for carbon capture, Water Res. 86 (2015) 108-115

[38] I. Gajda, J. Greenman, C. Melhuish, I.A. Ieropoulos, Electricity and disinfectant production from wastewater: Microbial Fuel Cell as a self-powered electrolyser, Sci. Rep. 6 (2016) 25571.

[39] I. Gajda, J. Greenman, C. Melhuish, C. Santoro, I. Ieropoulos, Microbial Fuel Cell-driven caustic potash production from wastewater for carbon sequestration, Bioresour. Technol. 215 (2016) 285-289.

[40] I. Gajda, A. Stinchcombe, J. Greenman, C. Melhuish, I. Ieropoulos, Microbial fuel cell-A novel self-powered wastewater electrolyser for electrocoagulation of heavy metals, Int. J. Hydrogen Energy (2016) http://dx.doi.org/10.1016/j.ijhydene.2016.06.161. 

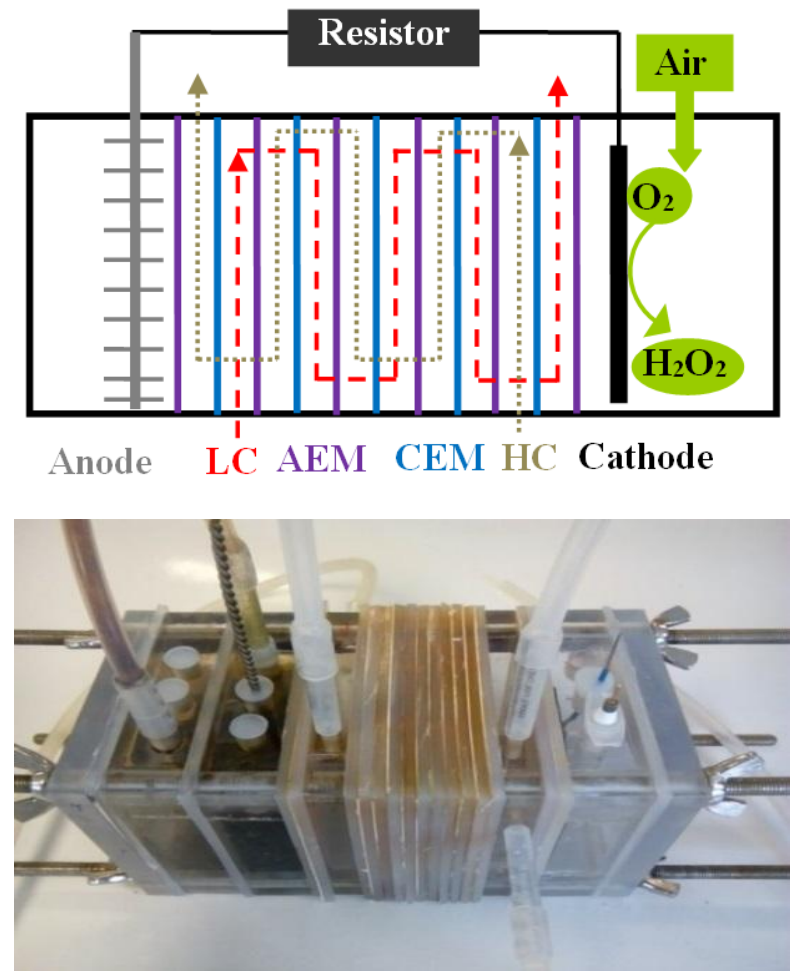

Fig. 1. 


\section{gure 2}

Click here to download Figure(s) - provide separately in addition to within the manuscript file: Figure 2.docx
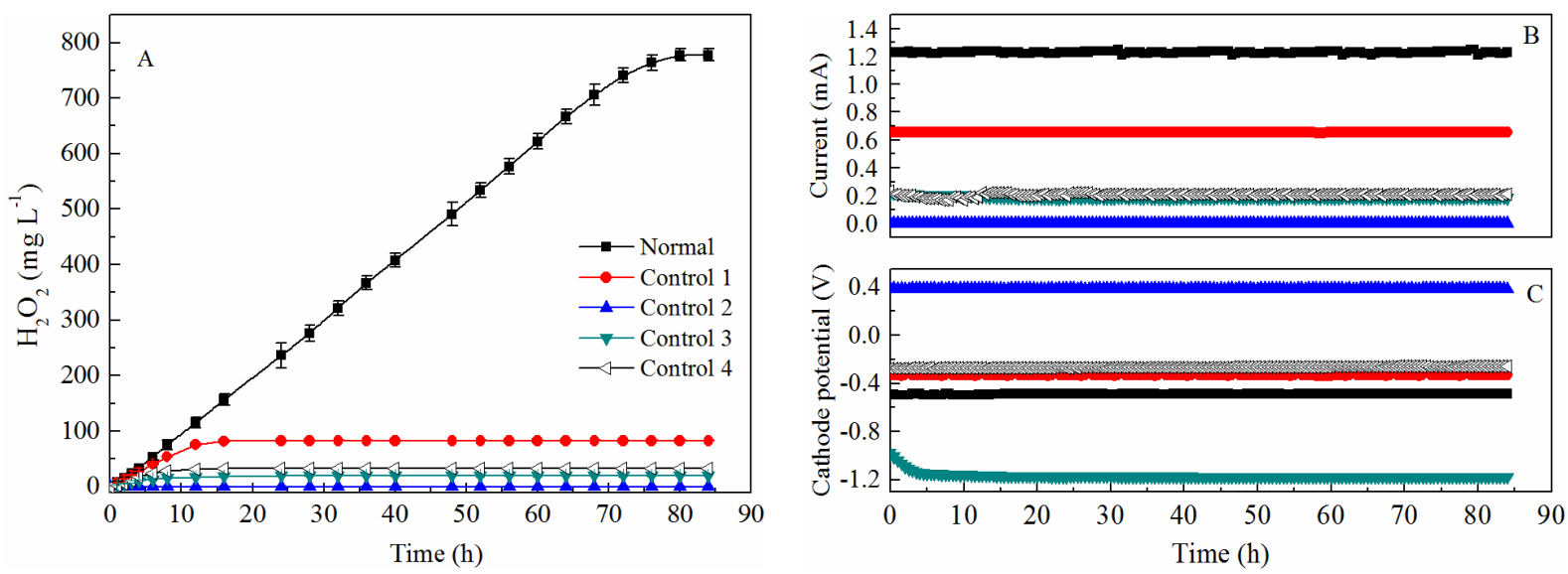

Fig. 2. 
Figure 3

Click here to download Figure(s) - provide separately in addition to within the manuscript file: Figure 3.docx
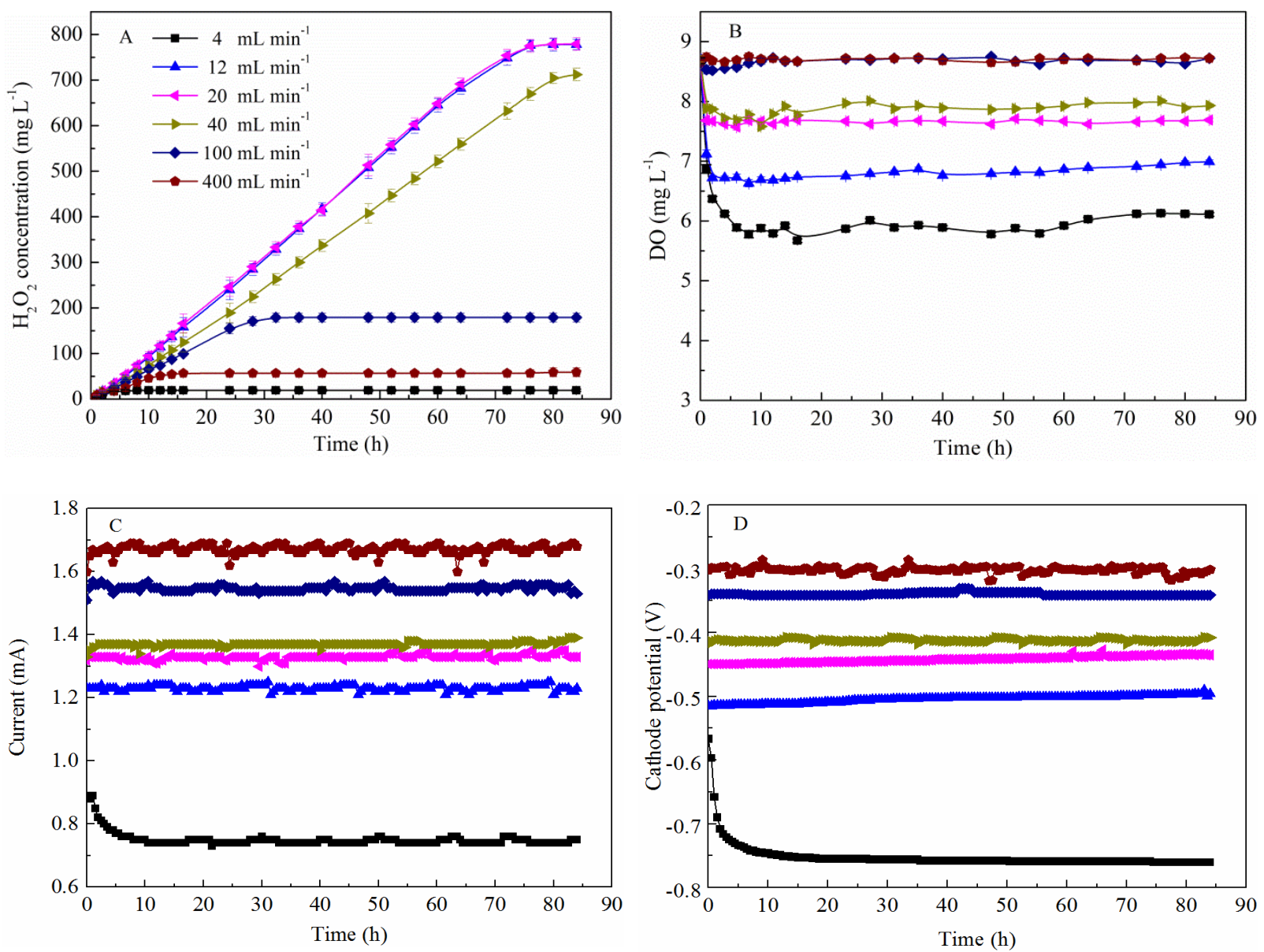

Fig. 3. 
Figure 4

Click here to download Figure(s) - provide separately in addition to within the manuscript file: Figure 4.docx
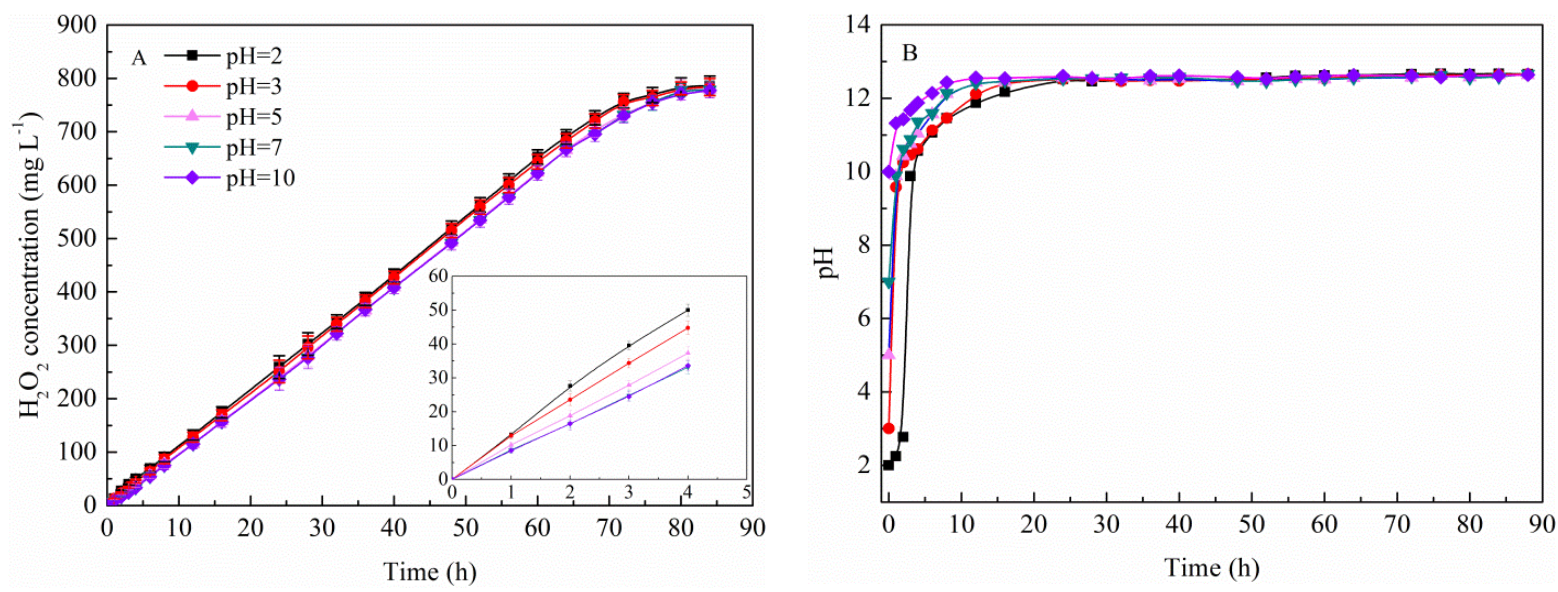

Fig. 4. 
Figure 5

Click here to download Figure(s) - provide separately in addition to within the manuscript file: Figure 5.docx
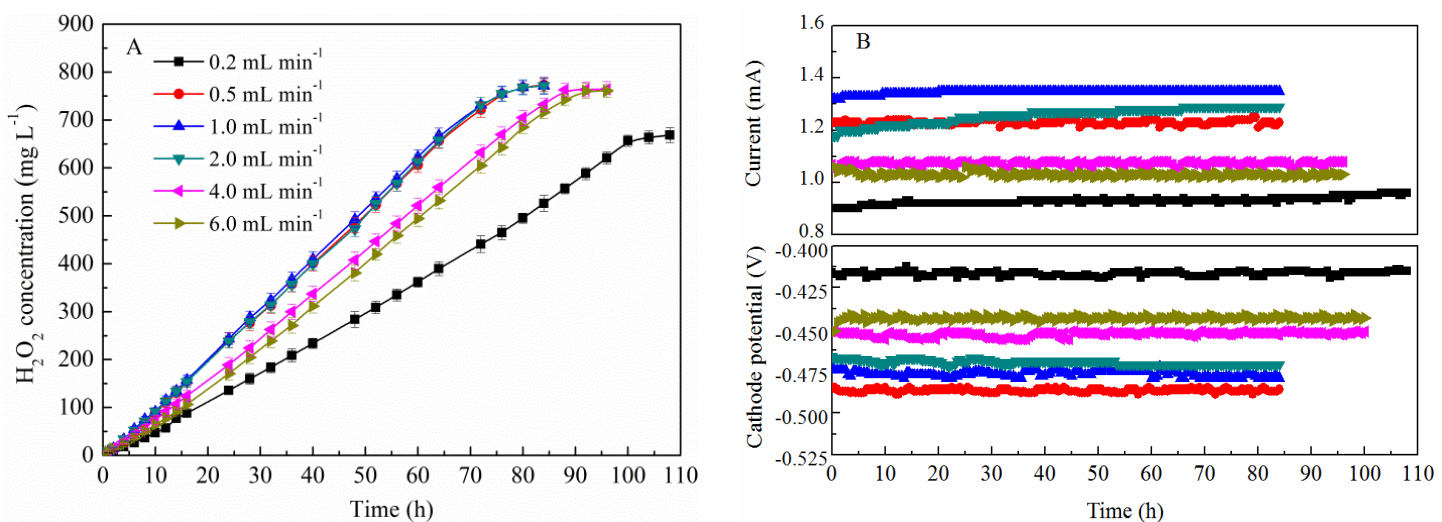

Fig. 5 
Click here to download Figure(s) - provide separately in addition to within the manuscript file: Figure 6.docx
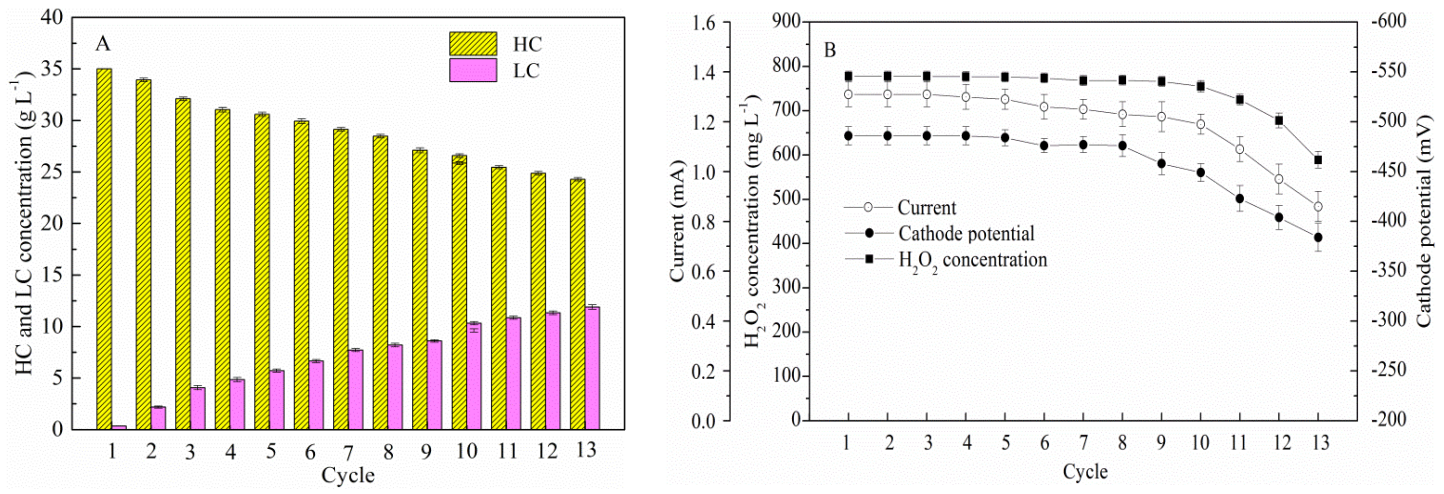

Fig. 6. 


\section{igure 7}

Click here to download Figure(s) - provide separately in addition to within the manuscript file: Figure 7.docx

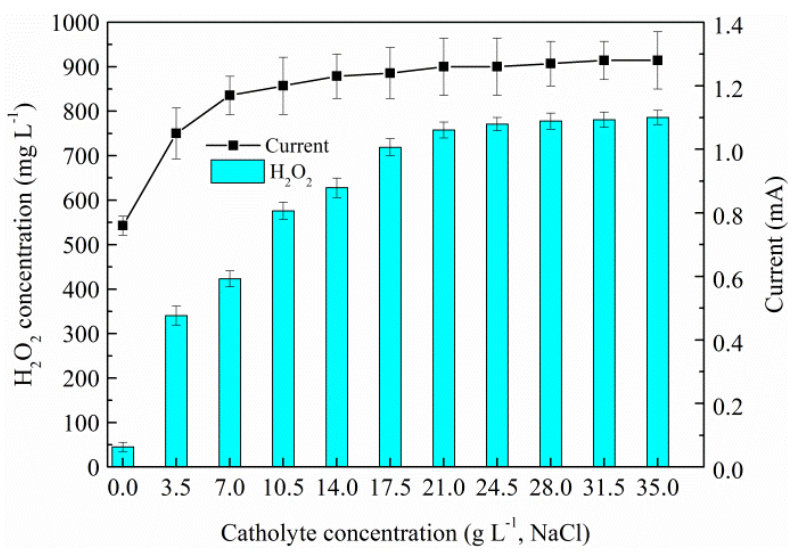

Fig. 7. 


\section{Figure and table captions}

Fig. 1. Schematic of MREC (CEM: cation exchange membrane, AEM: anion exchange membrane, HC: high concentration solution, LC: low concentration solution).

Fig. 2. The performance of MREC under normal and different control conditions (Normal: air flow rate of $12 \mathrm{~mL} \mathrm{~min}^{-1}$, catholyte $\mathrm{pH}$ of $7,0.5 \mathrm{~mL} \mathrm{~min}^{-1} \mathrm{HC}$ and LC solution flow in RED; Control 1: both $\mathrm{HC}$ and $\mathrm{LC}$ solution are $0.35 \mathrm{~g} \mathrm{~L}^{-1} \mathrm{NaCl}$ solution; Control 2: Open circuit; Control 3: No air flow in cathode chamber; Control 4: No microorganisms on the anode).

Fig. 3. The effect of air flow rate on the concentration of $\mathrm{H}_{2} \mathrm{O}_{2}(\mathrm{~A})$, DO (B), Current (C) and Cathode potential (D).

Fig. 4. The effect of initial $\mathrm{pH}$ on the $\mathrm{H}_{2} \mathrm{O}_{2}$ production in the MREC.

Fig. 5. The effect of $\mathrm{HC}$ and $\mathrm{LC}$ flow rate on the $\mathrm{H}_{2} \mathrm{O}_{2}$ production.

Fig. 6. The effect of $\mathrm{HC}$ and $\mathrm{LC}$ concentration on $\mathrm{H}_{2} \mathrm{O}_{2}$ generation.

Fig. 7. The effect of catholyte concentration on $\mathrm{H}_{2} \mathrm{O}_{2}$ generation.

Table 1. Performance of $\mathrm{H}_{2} \mathrm{O}_{2}$ synthesis using different microbial electrochemical technologies

Table 2. The COD removal, $R_{\text {cat }}, \mathrm{CE}$ and energy input under different operation conditions. 
